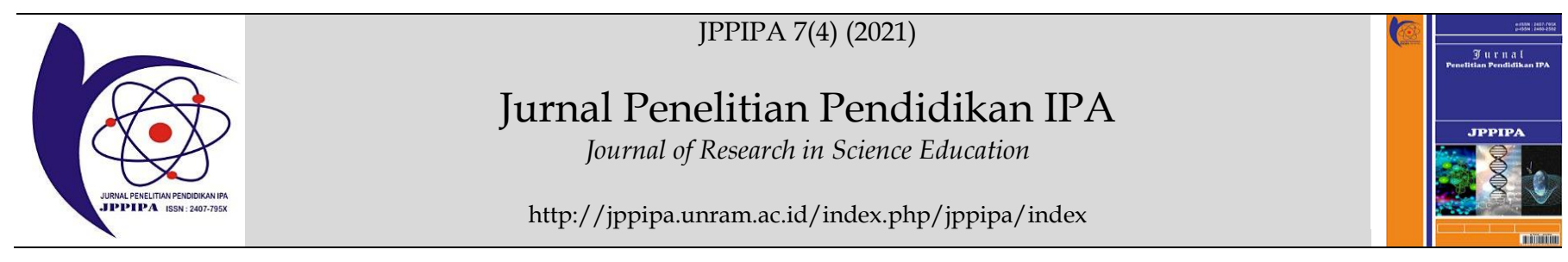

\title{
Independence of Learning and Achievement of Learners' Cognitive Abilities in Thermochemical Materials through the Application of Flipped Classroom
}

\author{
Ruhul Mukhlisa1 ${ }^{1}$ Abdul Gani 2*, Sri Winarni², Ibnu Khaldun², Latifah Hanum² \\ ${ }^{1}$ Master of Science Education Program, Postgraduate University of Syiah Kuala, Banda Aceh, Indonesia. \\ ${ }^{2}$ Chemistry Study Program, Faculty of Teacher Training and Education, University of Syiah Kuala, Banda Aceh, Indonesia
}

DOI: $\underline{10.29303 / \text { ippipa.v7i4.674 }}$

\section{Article Info}

Received: March 10th, 2021

Revised: August 24th, 2021

Accepted: September 22th, 2021

\begin{abstract}
The utilization of online media such as learning videos, e-books, e-libraries, and virtual laboratories as a source of independent learning by learners is still very low, as a result of which teachers are still the main source of learning. This shows the low independence of learning learners, even though independence is one-factor affecting learning achievement. The correct learning methods can increase the independence of learning learners, one of which is by applying flipped classrooms. This research aims to find out the effect of the application of flipped classrooms on learning independence and cognitive achievement of learners in thermochemical materials as well as the correlation of learning independence with the achievement of cognitive abilities of learners. This study is an experimental study with the design of two groups at random. The measuring instrument used is a matter of postest and learning independence questionnaire. The research data were analyzed using the SPSS for Windows program. The results found that learning independence and better achievement of cognitive abilities were shown in the group that applied the class upside down. There was a significant positive relationship between the achievement of cognitive ability and the independence of learning in both groups, both in classes that applied classes in reverse and in classes that did not apply inverse classes.
\end{abstract}

Keywords: flipped classroom; learning independence; cognitive ability achievement; thermochemistry.

Citation: $\quad$ Mukhlisa, R., Gani, A., Winarni, S., Khaldun, I., \& Hanum, L. (2021). Independence of Learning and Achievement of Learners' Cognitive Abilities in Thermochemical Materials through the Application of Flipped Classroom. Jurnal Penelitian Pendidikan IPA, 7(4), 523-530. doi:https://doi.org/10.29303/jppipa.v7i4.674

\section{Introduction}

Thermochemistry is one of the subjects for class XI with a fairly broad scope of material. It addresses the concepts of exothermic and endothermic reactions and the energy that comes with them. Characteristics of conceptual thermochemical material and contains algorithmic elements cause learners difficulty connecting interrelationships between sub-matter parts (Riani et al., 2016). Thermochemical materials that are considered difficult by learners include 1) system concepts, environment, reaction heat, and enthalpy; 2) the concept of standard enthalpy change; 3 ) the concept of calculating enthalpy change $(\Delta \mathrm{H})$ reaction, and 4$)$ the concept of stoichiometry in thermochemistry. Learners will have difficulty understanding thermochemical materials if they do not understand stoichiometry because thermochemical materials involve the concept of moles, equalization of chemical equations, and algebraic procedures (Zakiyah et al., 2018). Some of these difficulties are also experienced by learners in Aceh Province. This can be seen from the low 
percentage of learners who answered correctly related to thermochemical subjects, especially reaction enthalpy material at the national examination of the last three years at the Aceh province level, which was $28.2 \%$ in 2017, 35.8-38.5\% in 2018 and 30.5-33.1\% in 2019 (Puspendik, 2019).

Another problem faced is the outbreak of coronavirus pandemic 2019 (Covid-19) cases at the end of December 2019 which resulted in the physical closure of all types of educational institutions. Teachers and learners must master technology as a medium of learning because all learning processes are done from home online (Pal \& Vanijja, 2020). Before the pandemic, the use of technology such as internet utilization was very high among high school students, reaching $90.2 \%$ but not used as a source or learning medium but only for means of communication, social media, playing online games, watching movies, and other entertainment (APJII, 2018). This condition is further aggravated during a pandemic, and students spend a lot of digital interactions that sometimes have nothing to do with learning (Serambinews, 2020).

Factors that cause low use of the internet as a source or learning media to include 1) lack of parental tutoring towards children; 2) weak parental control over the use of the internet by children; 3) The weak intensity of teachers provides lesson tasks to utilize the internet; 4) low level of parental education; and 5) Lack of intensity of children in reading textbooks (Chalim \& Anwas, 2018). This shows that the weak awareness and independence of learning learners to use the internet as a source of learning, whereas the internet can be a very effective source for learning activities if planned properly (Özsoy-Güneş et al., 2016). A lot of information can be obtained by learners related to the subject matter through content provided online, such as learning videos, digital libraries, e-books, etc. A low level of internet use as a learning medium indicates the low independence of learning learners (Dedyerianto, 2019). Learners who have low learning independence will have an impact on low learning outcomes, while learners who have high learning independence will show high learning outcomes as well (Eidelmen \& Shwartz, 2016).

Independence of learning is one of the factors that are considered to affect the learning achievement of learners. Several studies have been conducted and proven successful in improving the independence of learning learners, including the application of problembased learning models assisted by Edmodo media and cooperative learning STAD combined with blended learning (Aulia et al., 2019; Trisnawati, 2018). Another alternative that can be used to increase the independence of learning learners in this study is to apply flipped classroom learning.
The flipped classroom is a learning program developed by Jonathan Bergmann and Aaron Sams in 2006 that combines instructional technology and active learning (Gasparic, 2017). The term flipped classroom or "reverse class" refers to the exchange of learning schemes. Generally, the subject matter in the form of basic knowledge (low-level thinking, such as remembering and understanding) is given in the classroom, then the application of knowledge (high level of thinking, such as applying and analyzing) is given the task as homework. Flipped classroom learning is the opposite before classes begin. Learners are asked to study at home through video learning or presentations with a short duration given by the teacher, then teaching and learning activities in class in the form of doing tasks, discussing materials or problems that learners do not yet understand (Lai \& Hwang, 2016). This is in line with what Goedhart (2019) explains that through a flipped-classroom approach, low-level learning (i.e., defining and understanding essential content) can occur outside the classroom, and deeper higher-level learning (i.e., applying and evaluating materials) can be achieved within the classroom.

The flipped classroom is suitable for application during pandemic times and after the end of pandemics. Through flipped classroom learning, learners will prepare themselves to learn the material discussed at the upcoming meeting to increase their learning independence (Choiroh et al., 2018). The flipped classroom is also effectively used against a fairly broad topic of discussion. At the same time, the time provided is very limited and positively influences learners' acquisition of cognitive learning outcomes (Ridha et al., 2016). In addition, flipped classrooms support the transition of traditional educational models to shift toward more flexible, effective, and active learning, as teachers can engage learners in more learning activities to apply the knowledge they have learned through practice, project work, discussion, and problem-solving in the classroom (Nouri, 2016; Saputra \& Mujib, 2018)

Based on the description above, research has been conducted to determine the independence of learning and the achievement of learners' cognitive abilities in thermochemical materials through the application of flipped classrooms.

\section{Method}

The study used experimental methods with quantitative approaches to two sample groups. Quantitative approach to directly test the independence of learning and the achievement of learners' cognitive abilities in thermochemical materials through the application of flipped classroom learning. The research 
design used is control group only posttest design to measure cognitive achievement of learners combined with a control group pretest-posttest design to measure learning independence. This study was conducted at Sma Negeri 3 Banda Aceh. The study sample of 67 learners consisted of 33 experimental class learners and 34 control class learners. The data analyzed in this study in the form of posttest data on the achievement of cognitive abilities and questionnaires of learners' learning independence. Posttest consists of 20 multiple choice questions with five alternative answers and one right answer choice, while the learning independence questionnaire consists of 25 statement items with four answer options. Data on the achievement of cognitive ability and learning independence of learners are analyzed by conducting normality tests, homogeneity tests, hypothesis tests, and correlation tests using SPSS (Statistic Package Social Science) software version 18.0 for windows.

\section{Result and Discussion}

\section{Achievement of Cognitive Abilities of Learners}

This study measured learners' cognitive abilities in thermochemical material by providing a posttest consisting of 20 multiple choice questions with five alternative answers. Test instruments are based on indicators of achievement of thermochemical material competence with achievement levels C4 (analysis) and C5 (evaluation). The results of the analysis of data on the achievement of cognitive abilities of learners can be seen as follows:

a. Test the Normality of Cognitive Ability Achievement of Learners

Results from the Kolmogorov-Smirnov test normality analysis for data on the cognitive abilities of experimental classroom learners and control classes are presented in table 1.

Table 1: Test the normality of learning cognitive ability achievement

\begin{tabular}{lllll}
\hline \multirow{2}{*}{ Class } & \multicolumn{3}{l}{ Kolmogorov-Smirnov } & \multirow{2}{*}{ Conclusion } \\
\cline { 2 - 4 } & Statistic & df & Sig. & \\
\hline Experiment & 0.149 & 33 & 0.061 & Normal \\
Control & 0.091 & 34 & 0.200 & Normal \\
\hline
\end{tabular}

Based on table 1, the achievement of cognitive abilities of experimental and control class learners has a value of significance greater than $\alpha=0.05$, which is 0.061 and 0.200. This shows that data on the achievement of cognitive abilities of experimental classroom learners and control classes are normally distributed.

\section{b. Test homogeneity of Achievement of Cognitive Abilities of Learners}

Results from the Levene Statistics test homogeneity analysis for data on the cognitive achievement of experimental classroom learners and control classes are presented in table 2.

Table 2. Test homogeneity of learners' cognitive ability achievement

\begin{tabular}{lllllll}
\hline Class & Achievement of Cognitive Ability & Levene Statistic & df1 & df2 & $\frac{\text { Sig. }}{65}$ & $\frac{\text { Conclusion }}{0.563}$ \\
\hline Experiment \& Control & Based on average values & 0.337 & Homogen \\
\hline
\end{tabular}

Based on table 2, the achievement of cognitive abilities of experimental and control class learners has a value of significance greater than $a=0.05$, which is 0.563. This suggests that data on the cognitive achievement of experimental classroom learners and control classes come from homogeneous variants.

\section{c. Test hypothesis of achievement of cognitive abilities of learners}

Results from the test analysis of differences in data on the achievement of cognitive abilities of experimental class learners and control classes are presented in table 3.

Table 3. Test hypothesis of achievement of cognitive abilities of learners

\begin{tabular}{|c|c|c|c|c|c|c|}
\hline Class & $\mathrm{N}$ & Mean & $\begin{array}{l}\text { Standard } \\
\text { Devices }\end{array}$ & $t_{\text {count }}$ & $\mathrm{t}_{\text {table }}$ & Sig. \\
\hline Experiment & 33 & 53.788 & 23.117 & \multirow{2}{*}{2.962} & \multirow{2}{*}{1.668} & \multirow{2}{*}{0.004} \\
\hline Control & 34 & 37.941 & 20.638 & & & \\
\hline
\end{tabular}

Based on table 3, the achievement of cognitive abilities of experimental and control class learners has $t_{\text {count }}=2.962>t_{\text {table }}=1.668$ with a value of two-sided significance (Sig.2-tailed) smaller than $\alpha=0.05$, which is 0.004 , meaning the achievement of cognitive abilities of experimental class learners is better than and control class.

The results of the data analysis showed that the achievement of cognitive abilities of learners in experimental classes that applied flipped classroom learning was better compared to control class learners who did not apply flipped classroom learning. This is because learners in the experimental class have studied in advance the material that will be discussed during online classes by watching and understanding learning videos shared by researchers before classes begin. After watching the learning video, learners create and write a summary of the material in their respective notebooks. Summary of the material includes types of reaction enthalpy along with examples of reaction equations 
(standard formation enthalpy, standard decomposition enthalpy and standard combustion enthalpy), how to determine $\Delta \mathrm{H}$ reactions using standard formation enthalpy data $(\Delta \mathrm{H} \circ)$, how to determine $\Delta \mathrm{H}$ of reactions using Hess cycle/law diagrams, how to determine $\Delta \mathrm{H}$ of reactions using bond energy data and stoichiometric concept relationships with reaction $\Delta \mathrm{H}$. In addition to making and understanding the summary that has been written, learners must note things that are not yet understood in order to ask as many questions and discussed them in class. The activity of one of the groups during the discussion can be seen in figure 1 .

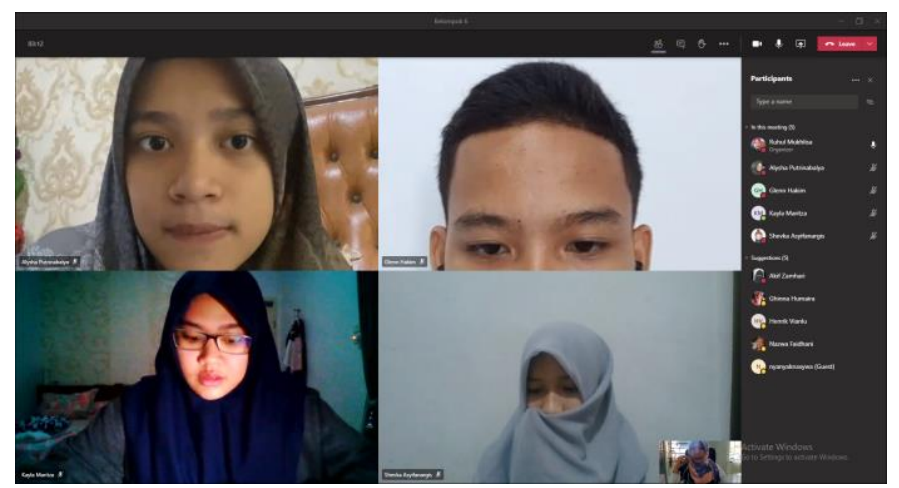

Figure 1. Student activities when discussing groups

Learners can use the time in the classroom to discuss solving problems, develop concepts and engage in collaborative learning, while researchers can streamline the time to interact with learners personally, helping them solve difficulties in understanding concepts and accommodate each idea so that classroom learning is more effective and quality, consequently achieving cognitive abilities will also be better. This is in accordance with the opinion of Putry et al. (2020), video-based learning media suitable for education in the current era 4.0. Learning video media causes learners to be unsaturated and can be a solution in the presentation of materials so as not to be monotonous. In addition, learning videos can guide self-learning and can be used anytime and anywhere. This medium is appropriately used for learners who are weak and slow in receiving content presented with text or presented verbally because the video can be played repeatedly as per the needs of learners.

The achievement of cognitive abilities of learners in the study class that applies flipped classroom by utilizing learning videos better than control classes in line with several other studies, such as those conducted by Mirlanda et al. (2020), the use of technologies such as learning videos becomes an attraction for learners. A learning atmosphere that suits the characteristics will make learning more enjoyable so that the improvement of learners' reasoning skills with flipped classroom learning is bigger than scientific learning. Nouri (2016) explained that the use of video as a learning tool is felt to reach and give a positive effect to low-achieving learners so that there is an increase in achievement and learning that is felt more effectively. Ridha (2016) added that flipped classroom learning has a positive influence on learners' cognitive learning outcomes.

\section{Achievement of Learners' Learning Independence}

Learning independence is the activity of learners who actively plan time and how to learn, set goals, and evaluate their ability to learn (Jansen et al., 2016). The learning independence questionnaire used is adapted from SOL-Q (self-regulated online learning questionnaire) developed by Jansen in 2016. The statement on the study questionnaire consists of 25 items with four answer options, namely: never (TP), sometimes (KK), often (SR), and always (SL). The data analysis results on the achievement of learners' learning independence can be seen as follows:

\section{a. Test the Normality of Learners' Learning Independence}

Results from the Kolmogorov-Smirnov test's normality anas for experimental classroom learning independence data and control classes are presented in table 4 .

Table 4. Test the normality of learners' learning independence

\begin{tabular}{|c|c|c|c|c|}
\hline \multirow{2}{*}{ Class } & \multicolumn{3}{|c|}{ Kolmogorov-Smirnov } & \multirow{2}{*}{ Conclusion } \\
\hline & Statistic & $\mathrm{df}$ & Sig. & \\
\hline Experiment & 0.140 & 33 & 0.098 & Normal \\
\hline Control & 0.099 & 34 & 0.200 & Normal \\
\hline
\end{tabular}

Based on table 4, the learning independence of experimental classroom learners and control classes has values of greater significance than $a=0.05$, i.e., 0.098 and 0.200 . This shows that data on the achievement of learning independence of experimental class learners and control classes are normal distribution.

\section{b. Test homogeneity of Learners' Learning Independence \\ Results from the Levene Statistics test} homogeneity analysis for experimental classroom and control class learners' learning independence data are presented in table 5 . 
Table 5. Test homogeneity of learners' learning independence

\begin{tabular}{llllllll}
\hline Class & Achievement of Cognitive Ability & Levene Statistic & df1 & df2 & Sig. & Conclusion \\
\hline Experiment \& Control & Based on average values & 1.012 & 1 & 65 & 0.318 & Homogen \\
\hline
\end{tabular}

Based on table 5, the learning independence of experimental classroom learners and control classes has a value of greater significance than $\alpha=0.05$, which is 0.318 . This suggests that the data on the learning independence of experimental class learners and control classes comes from homogeneous variants.

\section{c. Test the Student's Learning Independence Hypothesis}

Results from the test analysis of differences in data on the achievement of cognitive abilities of experimental classroom learners and control classes are presented in table 6 .

Table 6. Test the student's learning independence hypothesis

\begin{tabular}{|c|c|c|c|c|c|c|}
\hline Class & $\mathrm{N}$ & Mean & $\begin{array}{l}\text { Standard } \\
\text { Devices }\end{array}$ & $t_{\text {count }}$ & $t_{\text {table }}$ & Sig. \\
\hline Experiment & 33 & 23.867 & 13.114 & \multirow{2}{*}{2.492} & \multirow{2}{*}{1.668} & \multirow{2}{*}{0.015} \\
\hline Control & 34 & 16.521 & 10.946 & & & \\
\hline
\end{tabular}

Based on table 6, the learnability of experimental class learners and control classes has $t_{\text {count }}=2.492>t_{\text {table }}$ $=1.668$ with a two-sided significance value (Sig.2tailed) smaller than $a=0.05$ which is 0.015 . This shows that the independence of learning of experimental class learners is better than and the control class, then Ho is rejected, and $\mathrm{Hr}$ is accepted.

The results of the data analysis showed that the independence of learning learners in experimental classes that applied flipped classroom learning was better compared to control class learners who did not apply flipped classroom learning. This is because, in the experimental class, learners have first prepared themselves to follow the learning in the classroom by making summaries and noting things that are not yet understood from videos shared by researchers. At the first meeting, ten students did not watch the video and did not make a summary, perhaps because they were not familiar with flipped classroom learning. At the next meeting, learners began to get used to flipped classroom learning, characterized by no more learners who did not watch videos and make summaries and record things that have not been understood about thermochemical material. Learners have managed study time both at home and at school, created task completion targets, and compiled many questions to discuss in online classes. Things that learners have not understood are recorded and discussed together. One of the problems discussed by learners in the group can be seen in figure 2 .

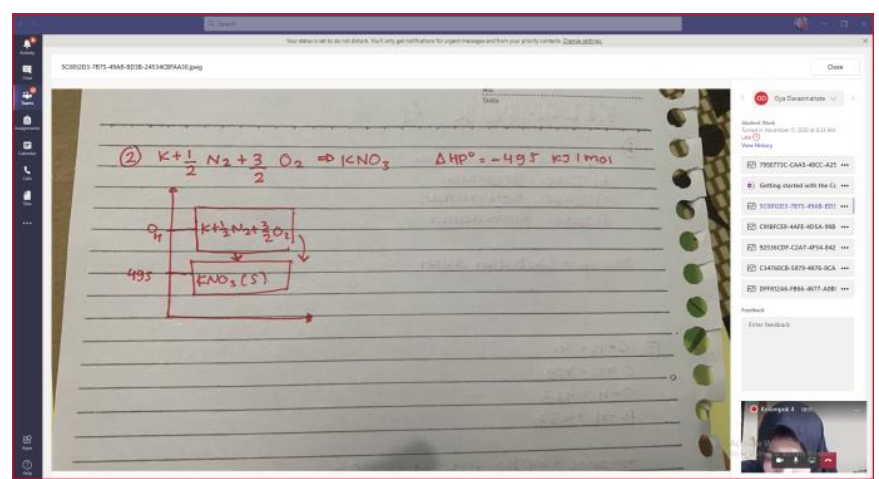

Figure 2. Issues discussed by one of the groups

Flipped classroom learning encourages learners to actively participate in decision making and have a wide opportunity to collaborate, explore and argue in discussions without being cut off time to learn basic concepts, thus providing space for learners to explore their knowledge independently, as a result of which the independence of learning learners will increase. This is in accordance with the opinion of Awidi and Paynter (2019), which favors the flipped classroom learning model as learning that provides freedom for learners to learn at their own pace, enabling the discovery of several solution strategies and, most importantly that learners can take property rights to their own learning, in other words, they learn independently.

The independence of learning of learners in the study class that applies flipped classroom is better than the control class in line with some other studies, such as those conducted by Sinaga (2017), learning methods greatly affect learning processes and outcomes. Varied and non-monotonous methods will increase interest and desire to learn, one of which is through the application of flipped classrooms. The application of flipped classroom learning successfully provides increased student learning independence in Basic Chemistry courses. Choiroh et al. (2018) explained that the achievement and independence of learning learners with flipped classroom learning are higher than learners who learn with conventional learning models. Muliadi et al. (2021) added that the support of all parties, such as teacher readiness, learners, and the learning environment, would increase the effectiveness of learning.

\section{Correlation Test of Achievement of Cognitive Ability of Learners and Independence of Learning}

The correlation test aims to see if learning independence data with the achievement of learners' cognitive abilities correlate or not. The correlation test 
was conducted using the Pearson test using the significance level of $a=0.05$. The testing criteria are as follows; 1) If Sig.2-tailed $>0.05$, the data is not correlated. 2) If Sig.2-tailed $<0.05$, then the data is correlated.

Results from Pearson's test correlation analysis for learning independence data and achievement of the cognitive abilities of experimental and control class learners are presented in table 7.

Table 7. Test correlation of achievement of cognitive abilities of learners and independence of learning

\begin{tabular}{|c|c|c|c|}
\hline Class & $\begin{array}{l}\text { Pearson } \\
\text { Correlation }\end{array}$ & $\mathrm{N}$ & Sig.(2-tailed) \\
\hline Experiment & 0.521 & 33 & 0.002 \\
\hline Control & 0.399 & 34 & 0.019 \\
\hline
\end{tabular}

Based on table 7, Pearson correlation test analysis results between cognitive achievement and learning independence in the experimental class obtained $r_{\text {count }}$ results $=0.521>r_{\text {table }}=0.203$ with a two-sided significance value (Sig.2-tailed) smaller than $a=0.05$ i.e. 0.002 and in the control class obtained $r_{\text {count }}$ results $=$ $0.399>r_{\text {table }}=0.203$ with a two-sided significance value (Sig.2-tailed) smaller than $\alpha=0.05$ which is 0.019 . This suggests that there is a significant positive relationship between cognitive achievement and learning independence in learners.

Learning independence is a strong desire accompanied by motivation from a learner to achieve the learning goals set. These learning goals can be achieved by preparing, organizing, controlling, and controlling aspects that affect how each learns. Learners who have learning independence must have a sense of responsibility towards learning. Learners who have a sense of responsibility for learning will strive to determine and manage their teaching materials, time, place, and utilize the necessary learning resources and find various alternatives in problem-solving so that cognitive achievement will also increase. This is in accordance with the opinion of Azmi (2016) learners who have good learning independence will have goals and learning strategies that lead to achieving a goal and managing time well. This causes his achievements to increase, and learning goals can be achieved optimally. Eidelmen \& Shwartz (2016) added that learners with high learning independence would provide high learning outcomes. Conversely, low learning independence results in low learning outcomes. Rahmadani et al. (2021) also emphasized the importance of the role of parents is very important in accompanying the success of children during home study. Parents play a role in guiding the basis of attitudes and skills, such as religious education to obey the rules and for good habituation, but now the role is increasingly widespread, namely as a companion to academic education.

\section{Conclusion}

Research and discussions concluded that the independence of learning and the achievement of cognitive abilities of learners who apply flipped classroom learning are better than learners who do not apply flipped classroom learning on thermochemical materials. There is a significant positive relationship between cognitive achievement and the learning independence of learners both in classes that apply flipped classroom learning and those who do not apply flipped classroom learning.

\section{References}

APJII. (2018). Hasil Survei Internet APJII 2018. Retrieved from: https://apjii.or.id/survei.

Aulia, L. N., Susilo, S., \& Subali, B. (2019). Upaya peningkatan kemandirian belajar siswa dengan model problem-based learning berbantuan media Edmodo. Jurnal Inovasi Pendidikan IPA, 5(1), 69-78. doi:https://doi.org/10.21831/jipi.v5i1.18707 [Indonesian]

Awidi, I.T. \& Paynter, M. (2019). The impact of a flipped classroom approach on student learning experience. Computers $\mathcal{E}$ Education.

Azmi, S. (2016). Self Regulated Learning Salah Satu Modal Kesuksesan Belajar Mengajar. Seminar ASEAN 2nd Psychology \& Humanity @ Psychology Forum UMM, 19-20 Februari 2016.

Chalim, S., \& Anwas, E. O. M. (2018). Peran Orangtua dan Guru dalam Membangun Internet sebagai Sumber Pembelajaran. Jurnal Penyuluhan, 14(1), 33-42.

https://doi.org/10.25015/penyuluhan.v14i1.195 58. [Indonesian]

Choiroh, A. N. L., Ayu, H. D., \& Pratiwi, H. Y. (2018). Pengaruh model pembelajaran flipped classroom menggunakan metode mind mapping terhadap prestasi dan kemandirian belajar fisika. Jurnal Pendidikan Fisika, 7(1), 1-5. [Indonesian]

Dedyerianto, D. (2020). Pengaruh Internet dan Media Sosial terhadap Kemandirian Belajar dan Hasil Belajar Siswa. Al-TA'DIB, 12(2), 208. https://doi.org/10.31332/atdbwv12i2.1206.

[Indonesian] doi:https://doi.org/10.1016/j.compedu.2018.09. $\underline{013}$.

Eidelmen, R. R. \& Shwartz, Y. (2016). E-learning in chemistry education: self-regulated learning in a virtual classroom. $13^{\text {th }}$ International Conference on 
Cognition and Exploratory Learning in Digital Age (CELDA), ISBN: 978-989-8533-55-5:297-302.

Gasparic, R.P. (2017). Jonathan Bergmann and Aaron Sams, Flipped Learning: Gateway to Student Engagement, International Society for Technology in Education: Eugene, Oregon and Washington. CEPS Journal, 7(Chapter 12), 173176.

https://pdfs.semanticscholar.org/568c/f703d44c 70f69de85931dc4e43d05ad37707.pdf

Goedhart, N. S., Blignaut-van Westrhenen, N., Moser, C., \& Zweekhorst, M. B. M. (2019). The flipped classroom: supporting a diverse group of students in their learning. Learning Environments Research, 22(2), 297-310. doi: https://doi.org/10.1007/s10984-019-09281-2

Jansen, R.S., Leeuwen, A.V., Janssen, J., Kester, L., \& Kalz, M. (2016). Validation of the self-regulated online learning questionnaire. J Comput High Educ, 29, 6-27. doi:https://doi.org/10.1007/s12528-016-9125-x.

Lai, C.-L., \& Hwang, G.-J. (2016). A self-regulated flipped-classroom approach to improving students' learning performance in a mathematics course. Computers \& Education, 100, 126-140. https://doi.org/https://doi.org/10.1016/j.comp edu.2016.05.006

Mirlanda, E. P., Nindiasari, H., \& Syamsuri, S. (2020). Pengaruh Pembelajaran Flipped Classroom Terhadap Kemampuan Penalaran Matematis Ditinjau Dari Gaya Kognitif Siswa. Prima: Jurnal Pendidikan Matematika, 4(1), https://doi.org/10.31000/prima.v4i1.2081. [Indonesian]

Muliadi, A., Prayogi, S., Bahalwan, F., Nirmala, W., \& Verawati, N. (2021). Online learning during the Covid-19 pandemic: preservice teacher's perception. Jurnal Penelitian Pendidikan IPA, 7(3), 464-467.

doi:https://doi.org/10.29303/jppipa.v7i3.787.

Nouri, J. (2016). The flipped classroom: for active, effective and increased learning - especially for low achievers. International Journal of Educational Technology in Higher Education, 13(1). doi:https:// doi.org/10.1186/s41239-016-0032-Z.

Özsoy-Güneş, Z., Güneş, İ., \& Kırbaşlar, M. (2014). Investigation of the Relationships between Educational Internet Use Self-efficacy Beliefs and Self-regulated Learning Skills. Procedia - Social and Behavioral Sciences, 152, 708-713. https://doi.org/10.1016/j.sbspro.2014.09.308

Pal, D., \& Vanijja, V. (2020). Perceived usability evaluation of microsoft teams as an online learning platform during Covid-19 using system usability scale and technology acceptance model in India. Children and Youth Services Review, 119(July), 105-535. doi: https://doi.org/10.11591/edulearn.v8i4.384

Puspendik. (2019). Laporan Hasil Ujian Nasional. Retrieved from: https://hasilun.puspendik.kemdikbud.go.id..

Putry, H. M. E., 'Adila, V. N., Sholeha, R., \& Hilmi, D. (2020). Video Based Learning Sebagai Tren Media Pembelajaran Di Era 4.0. Tarbiyatuna: Jurnal Pendidikan Ilmiah, 5(1), 1-24. Retrieved from

http://ejournal.kopertais4.or.id/mataraman/in dex.php/tarbiyatuna/article/view/3870. [Indonesian]

Rahmadani, D., Chastanti, I., \& Harahap, D. (2021). Parents' role in biology learning during the Covid-19 pandemic. Jurnal Penelitian Pendidikan IPA, 7(2), 137-142. doi: https://doi.org/10.29303/jppipa.v7i2.583.

Riani, B., Budiasih, E., \& Suharti. (2016). Instrumen Pembelajaran Siswa SMK pada materi termokimia menggunakan model pembelajaran search, solve, create, and share (SSCS) berbantuan kartu masalah. Prosiding Pendidikan IPA Pascasarjana UM, 1:558-567. ISBN:978-6029286-21-2. [Indonesian]

Ridha, M., Setyosari, P., \& Kuswandi, D., (2016). Pengaruh flipped mastery classrom kognitif mahasiswa. Jurnal Pendidikan, 1(2), 655-661. Retrieved from http://journal.um.ac.id/index.php/iptpp/articl e/view/6211/2646. [Indonesian]

Saputra, M. E. A., \& Mujib, M. (2018). Efektivitas Model Flipped Classroom Menggunakan Video Pembelajaran Matematika terhadap Pemahaman Konsep. Desimal: Jurnal Matematika, 1(2), 173. doi:https://doi.org/10.24042/djm.v1i2.2389. [Indonesian]

Serambi News (2020). Cara cegah anak kecanduan internet saat pandemi. Retrieved from: https://aceh.tribunnews.com.

Sinaga, K. (2017). Pengaruh penerapan flipped classroom pada mata kuliah kimia dasar untuk meningkatkan self regulated learning. EduChemia (Jurnal Kimia dan Pendidikan), 3(1), 1932-1944. doi:https://doi.org/10.30870/educhemia.v3i1.26 26. [Indonesian]

Trisnawati, A. (2018). Students self regulated learning in stad cooperative learning combined with blended learning in instrumental analytical chemistry course. Pijar MIPA, X(1), 6-18. doi: http://dx.doi.org/10.29303/ipm.v13i1.409

[Indonesian]

Zakiyah., Ibnu, S., \& Subandi. (2018). Analisis dampak kesulitan siswa pada materi stoikiometri 
terhadap hasil belajar termokimia. Educhemia,

3(1), 119-134. doi:

http://dx.doi.org/10.30870/educhemia.v3i1.178

$\underline{4}$ 